\title{
Archaeology, the Caddo Indian Tribe, and the Native American Graves Protection and Repatriation Act
}

Mary C. Carter

Unknown

Follow this and additional works at: https://scholarworks.sfasu.edu/ita

Part of the American Material Culture Commons, Archaeological Anthropology Commons, Environmental Studies Commons, Other American Studies Commons, Other Arts and Humanities Commons, Other History of Art, Architecture, and Archaeology Commons, and the United States History Commons

Tell us how this article helped you.

This Article is brought to you for free and open access by the Center for Regional Heritage Research at SFA ScholarWorks. It has been accepted for inclusion in Index of Texas Archaeology: Open Access Gray Literature from the Lone Star State by an authorized editor of SFA ScholarWorks. For more information, please contact cdsscholarworks@sfasu.edu. 
Archaeology, the Caddo Indian Tribe, and the Native American Graves Protection and Repatriation Act

Creative Commons License

(c) (i) (9)

This work is licensed under a Creative Commons Attribution-NonCommercial 4.0 International License 


\title{
ARCHAEOLOGY, THE CADDO INDIAN TRIBE, AND THE NATIVE AMERICAN GRAVES PROTECTION AND REPATRIATION ACT
}

\author{
Mary Cecile Carter \\ Caddo Indian Tribe of Oklahoma
}

Caddo leadership has a long history of working cooperatively with foreign governments. In the seventeenth century, they cooperated with Spanish officials and missionaries who wanted to establish themselves among the southern branch of Caddo tribes--the Hasinai in Northeast Texas. In the eighteenth century, they cooperated with the French who wanted to establish trading posts on the Red River among the Natchitoches and Kadohadacho. In the nineteenth century they cooperated with Americans to establish peaceful relationships with unfriendly tribes (see Carter 1995). For Caddos, the result of these cooperative efforts was disillusion, decimation, displacement, and finally dispossession. Now, with new hope in the twentieth century, Caddo leaders have again pledged cooperation. This time with agencies, institutions, and individuals affected by an act of the United States Congress: the Native American Graves Protection and Repatriation Act (NAGPRA). They do so with a desire to reach mutually satisfactory agreements for the return of some part of what was lost in previous time: respect for their dead and recognition that only living descendants have the right to possess cultural items that belonged to Caddo ancestors.

A foundation for the Caddo Tribes' willingness to work toward mutually satisfactory agreements within the framework of NAGPRA was laid before the legislation was enacted. It began to be built several years ago as a few archaeologists, anthropologists, and curators became sensitive to the fact that there are living Caddo people who are directly linked to human remains and artifacts uncovered in Caddo sites, deposited in museums or laboratories, subjected to analysis, and reported on in professional journals. Several came to meet Caddo people living near the tribal center located a few miles north of Anadarko 
and east of Binger, Oklahoma. Some individual friendships developed from repeated visits. Caddos who met these people who studied their culture listened with deep interest to what they were told about mounds and villages built by their ancestors; they looked at pictures of artifacts shown to them as examples of the splendid work of ancient Caddo artists; and they received reassurance that theirs had been a superior culture. Most of all, though, they were bewildered--"What did they have to dig them up for-- why did they do that?"

My acquaintance with professionals in the field of Caddoan studies began in 1972 when I first attended a Caddo Conference and heard things about Caddos I had never heard before. It was about that time that I seriously began to research Caddo history--collecting written materials and oral histories. As far as prehistory was concerned, I discovered that the archeologists knew more about Caddos than Caddos did. So, I went to field school-with the Arkansas Archeological Society (AAS) at Caddo Gap in 1975; I gratefully received instruction in generous conversations with Dr. Clarence Webb and R. King Harris; I attended more field schools: the latest with the Texas Archeological Society at the Roitsch site (41RR16) and the AAS at Winding Stair. Over time, I cracked the academic code so that I could read a field report and understand most of it, and I learned that archeology offered my people a knowledge about the ancient ones that no other study could. I also understood that the knowledge was unavailable to a majority of Caddos. Most had never been able to see the magnificent products of the past, taken from the graves of their ancestors and exhibited by museums or sequestered in vaults. The objects were part of our heritage--proud evidence of our strength and culture--but only a few Caddos had the opportunity to travel and visit museums distant from their present homes to view them.

In January 1993, I was at a general membership meeting when the Chairman announced that he had received a letter about Caddo human remains that had been uncovered, and the writer wanted to know what the Caddos wanted to be done. Again, there were the bewildered mummers--why did they dig them up? Why did they do that? 
There were no answers. Only hurt. Afterwards, I told the Chairman I could help, and almost instantly I became Cultural Liason for the Caddo Tribe.

At that time I knew little about NAGPRA, and I understood even less that I had volunteered for a full time job. What I did know was that my tribe needed answers to the questions, "Why did they dig them up? How do they know they're Caddos? What should we do?" Explanation, information, trust, and belief were required.

As NAGPRA took effect, it became apparent that supplying answers to questions asked by members of the Tribe was beyond our resources. Agencies and institutions fulfilled their mandates for consultation by providing us with summaries. We received 183 notices; a few more arrived late. The paper work alone was staggering. A cursory review of the summaries made evident that a wealth of our cultural heritage was held by numerous museums and institutions. Bones of our kindred, and the things provided for them to journey from this life to the next lay in boxes on shelves or under spotlights in display cases instead of resting undisturbed in mother earth.

In this world, today, it is true that economics often interfere in controlling whai is right. NAGPRA, trying to right wrongs, placed a hardship on both Indian people of few resources and those people in charge of the repositories for objects subject to repatriation. We are not one of the rich tribes. Our income barely accomodates basic expenses for tribal administration. We have no ready funds for clerical help, research, consultants, or travel to view holdings. Caddos, acutely aware of the moral burden of caring for their own, needed assistance. Our assets were "Taysha" (the Caddo word for Friends).

When grant funds were made available through the National Park Service, we called upon our friends and they responded with commitments to support us in reaching cooperative agreements for repatriation through consultation and documentation. Darrell Creel, Curator of the Texas Archeological Research Laboratory; Julie Droke, Collections Manager, Oklahoma Museum of Natural History; Tom Green, Director of the Arkansas Archeological Survey; Hiram F. Gregory, Department of Anthropology, Northwestern 
State University of Louisiana; and Sue Linder-Linsley, Director and Collections Management, Department of Anthropology, Southern Methodist University, all provided letters of support. Tim Perttula, Assistant Director for Antiquities Review for the Texas Historical Commission's Department of Antiquities Protection agreed to conduct a workshop to assist the Caddo Tribe in the identification of Caddo-affiliated cultural items (see Perttula 1995).

The Caddo Tribe was rewarded with a grant which enables us to employ personnel to prepare a database of summaries and inventory information; prepare a bibliography and summary of information available to document Caddo cultural affiliation; review our reburial policy and revise it if necessary; hold a training session on basic techniques for identifying Caddo sites and cultural objects; arrange visits and consultations with museums holding important Caddo collections; undertake a professional assessment of our Culture Center to determine our ability to provide adequate care, treatment, and storage of repatriated cultural objects; and prepare a plan for the care and treatment of culturally affiliated human remains and cultural objects. All of these provisions are in accord with the intent of the Caddo Tribe to cooperate in reaching mutually satisfactory agreements on repatriation with responsible representatives of museums and federal agencies. To help carry out our objectives, the Caddo Tribe's Council has authorized the formation of the Caddo Cultural and Heritage Committee and charged it with the responsibility for oversight of the Caddo Culture Center, its educational programs, and activities. A Taysha Fund dedicated to support the Center and its projects has been established to receive gifts and donations.

We believe that the award of the National Park Service NAGPRA grant may at last vindicate the age-old Caddo policy of cooperation with others to achieve a common goal. The goal in this case being the return of reverence for our dead by others, and the renewal of Caddo prode in the accomplishments of our ancestors. 


\section{ACKNOWLEDGMENTS}

This paper was originally presented at the November 1994 Native American Graves Protection and Repatriation Act Compliance Workshop, Museum of Texas Tech University, Lubbock, Texas.

\section{REFERENCES}

Carter, C. E.

1995 The Caddo Indians: Where We Come From. University of Oklahoma Press, Norman.

Perttula, T. K.

1995 Caddoan Archeological and Historical Workshop for the Caddo Tribe of Oklahoma in Support of their Native American Graves Protection and Repatriation Act Grant. Caddoan Archeology Newsletter V (No. 4):15-18. 